\title{
Evaluation on Landscape Change Using Remote Sensing and Landscape Metrics: A Case Study of Sakaerat Biosphere Reserve (SBR), Thailand
}

\author{
Intareeya Sutthivanich and Suwit Ongsomwang
}

\begin{abstract}
Biosphere reserve is designed as an international model for exchange knowledge and experiences on sustainable development innovations across national and continental borders. To provide baseline information for future planning and management on biodiversity and environmental conservation this research investigated and evaluated the changes on landscape pattern in the Sakaerat Biosphere Reserve (SBR) of Thailand from 1980 to 2010. Multi-temporal remote sensing, geographic information system, and landscape metrics were applied to classify and analyze changes on landscape types and patterns. SBR landscape was classified into 6 landscape types and then four aspects of landscape metrics were applied to measure SBR landscape structure. The results showed that the natural forest landscape was the major landscape type, followed by the agriculture and the disturbed forest landscapes. Landscapes change occurred mostly in the disturbed forest, forest plantation and the urban landscapes. For landscape metrics measurement, it was found that the SBR landscape pattern variations occurred in increasing of fragmentation and diversity whereas decreasing occurred in core area and shape complexity at landscape level. Concurrently, at class level the indices indicated distinctively the trend of fragmentation, isolation, aggregation and extent of core area in the urban, forest plantation, agriculture, and the disturbed forest class.
\end{abstract}

Index Terms - Landscape change, landscape metrics, remote sensing.

\section{INTRODUCTION}

The monitoring of spatial and temporal changes in the landscape helps researchers to characterize and understand the pattern of interaction and connections of ecological and cultural communities across the landscape [1]-[4], and [5]. One of the most important environmental pressures which impact on natural landscapes and the ecosystem services is human disturbances on land use/land cover and landscape changes [6]-[9]. To date, researches in the field of landscape ecology have been extensively conducted in which focuses on interactions between people and the biosphere and have increased assurance to conservation of biodiversity and sustainable development [10]-[14]. Geospatial information such as remote sensing (RS) and geographical information systems (GIS) have emerged as key geospatial tools to satisfy

Manuscript received April 5, 2014; revised July 10, 2014. This work was supported in part by the Suranaree University of Technology and Geo-Informatics and Space Technology Development Agency (Public Organization), Thailand.

Intareeya Sutthivanich and Suwit Ongsomwang are with the School of Remote Sensing, Institute of Science, Suranaree University of Technology, Nakhon Ratchasima, 30000, Thailand (e-mail: suttin1@sut.ac.th, suwit@)sut.ac.th). increasing information needs of resource managers and ecologists [15]-[18]. Simultaneously, landscape pattern analysis approaches using landscape indices also widely spread to collaborate to achieve for valuable information in the same conduct because it is important for detecting and monitoring spatial pattern and changes of the landscape [19]-[22].

As the Sakaerat Biosphere Reserve (SBR) is the first leading biodiversity hotspot in Thailand and is designed as an international model for exchange knowledge and experiences on sustainable development innovations across national and regional landscape. It organizes into core area, buffer and transition zones in order to protection of biodiversity, sustainable resource use and ecosystem conservation. Numbers of research had previously been conducted in the biosphere reserves [23]-[26]. The central ideas of this research were to investigate and discuss the changes observed in the SBR landscape pattern and structure over time by classified multi temporal remote sensing datasets into landscape types and applied landscape indices to characterize landscape structure at landscape and class levels in order to obtain the baseline on landscape ecological information for further protection of the existing natural resources, establish landscape linkages, reduce fragmentation, enhance biodiversity, and restore ecosystems.

\section{MATERIALS AND METHODS}

\section{A. Study Area}

The Sakaerat Biosphere Reserve (SBR) was originally established in 1967 as an environmental research station and was extended as biosphere reserve in 1977 under the support of United Nations Educational, Scientific, and Cultural Organization (UNESCO) on Man and the Biosphere (MAB) programme covered the area of 1,632.48 sq. km. [27]. As for facilitating ecological and environmental research, SBR is also sustaining balance between the goals of conserving biological diversity, promoting economic development, and maintaining cultural values. It lies in Wang Nam Khieo and Pak Thong Chai districts, Nakhon Ratchasima province, Thailand (Fig. 1).

\section{B. Materials}

Remotely sensed and GIS datasets had been collected for this study while basic equipment such as hardware and software were employed for data collecting and data analysis (Table I).

\section{Methodology}

Research methodology was designed to meet the 
objectives of the research, which were involved classifying and evaluating on spatial landscape pattern in SBR. The method consists of three parts as shown in Fig. 2.

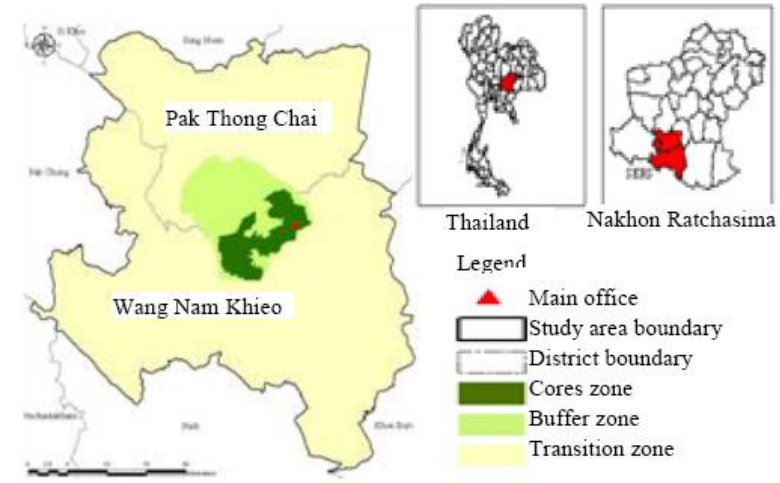

Fig. 1. Study area location and boundary.

TABLE I: DATASET AND EQUIPMENT

\begin{tabular}{lcll}
\hline $\begin{array}{l}\text { Dataset/ } \\
\text { Equipment }\end{array}$ & Date & $\begin{array}{l}\text { Resolution/ } \\
\text { Scale }\end{array}$ & Source \\
\hline $\begin{array}{l}\text { 1. Remote sensing datasets } \\
\text { 1.1 Black and White Aerial } \\
\text { Photographs }\end{array}$ & 1980 & $1: 40,000$ & RTSD \\
$\begin{array}{l}\text { 1.2 Digital Color Ortho } \\
\text { photographs }\end{array}$ & 2002 & $1: 4,000$ & MOAC \\
$\begin{array}{l}\text { 1.3 THEOS Pansharpened } \\
\text { 2. GIS datasets }\end{array}$ & 2010 & $2 \times 2 \mathrm{~m}$ & GISTDA \\
$\begin{array}{l}\text { 2.1 Topographic map } \\
\text { 2.2 Land use data }\end{array}$ & 1999 & $1: 50,000$ & RTSD \\
\hline
\end{tabular}

3. Equipment

3.1 Software: ERDAS Imagine, ESRI ArcGIS,

FRAGSTAT, and Patch Analyst

3.2 Hardware: GPS, Computer

RS Lab, SUT

Note: RTSD = Royal Thai Survey Department, MOAC = Ministry of Agriculture and Cooperative, GISTDA = Geo-Informatics and Space Technology Development Agency(Public Organization), LDD = Land Development Department, SUT =Suranaree University of Technology

\begin{tabular}{|l|l|}
\hline \multicolumn{2}{|c|}{ Evaluation on Landscape Change and Landscape Metrics } \\
\hline \multicolumn{2}{|c|}{ INPUT } \\
\hline 1. RS Datasets & 2. GIS Datasets \\
- B\&W Aerial Photographs 1980 & Topographic map \\
(55 scenes) & - Land use map \\
- Color Orthophotographs 2002 & - Political boundaries map \\
(245 scenes) & - Transportation, villages and \\
- THEOS Pansharpened 2010 & other settlement maps \\
(7 scenes) & \\
\hline
\end{tabular}

PROCESS

1. Data preparation and preprocessing

- Image rectification, Image mosaic, Image color enhancement

2. Visual image interpretation and on screen digitizing

- On-screen digitize in ArcGIS interface tools using basic key elements

of visual interpretation and in cooperate with ancillary data

- Classification of 6 landscape types in 1980, 2002, 2010

3. Landscape Indices analysis

- Calculation for landscape indices values at landscape and class levels using Patch Analyst and FRAGSTAT under ArcGIS interface tools

-Landscape level:(Indices: NP, ED, MSI, TCA, MCA, SDI, IJI, MNN) -Class level:(Indices: NP, ED, MSI, MCA, IJI, MNN)

OUTPUT

1. Landscape Type Distribution Maps(1980, 2002, 2010)

2. Landscape Change Evaluation (1980-2002 and 2002-2010)

3. Landscape Indices Measurement and Change(1980, 2002, 2010)

-At Landscape level and Class level

\section{RESULTS AND DISCUSSION}

\section{A. Landscape Type Classification and Distribution}

Based on SBR land use and land cover classification and accuracy assessment discussed by Sutthivanich [28]; the study area was modified and characterized into six landscape types which were 1) agricultural landscape, 2) natural forest landscape, 3) disturbed forest landscape, 4) forest plantation landscape, 5) urban landscape, and 6) miscellaneous landscape (e.g., water body, road, and idle area). From the process derived SBR landscape type distribution maps, including area and percentage of each landscape type in 1980, 2002, and 2010 (Table II and Fig. 3). Subsequently, evaluation of landscape changes was reported (Table III).

TABLE II: LANDSCAPE TYPES COVERAGE IN 1980, 2002, AND 2010

\begin{tabular}{|c|c|c|c|c|c|c|}
\hline \multirow{2}{*}{$\begin{array}{l}\text { Landscape } \\
\text { Type }\end{array}$} & \multicolumn{2}{|c|}{1980} & \multicolumn{2}{|l|}{2002} & \multicolumn{2}{|l|}{2010} \\
\hline & $\mathrm{Km}^{2}$ & $\%$ & $\mathrm{Km}^{2}$ & $\%$ & $\mathrm{Km}^{2}$ & $\%$ \\
\hline A & 641.47 & 39.29 & 670.34 & 41.06 & 674.01 & $\begin{array}{l}41.2 \\
8\end{array}$ \\
\hline NF & 754.63 & 46.23 & 724.53 & 44.38 & 724.78 & 44.4 \\
\hline DF & 166.82 & 10.22 & 76.34 & 4.68 & 65.1 & 3.99 \\
\hline FP & 26.23 & 1.61 & 67.62 & 4.14 & 60.59 & 3.71 \\
\hline $\mathrm{U}$ & 22.16 & 1.36 & 38.14 & 2.34 & 48.58 & 2.98 \\
\hline M & 21.17 & 1.29 & 55.51 & 3.4 & 59.42 & 3.64 \\
\hline Total & $1,632.48$ & 100 & $1,632.48$ & 100 & $1,632.48$ & 100 \\
\hline
\end{tabular}

In Table II, the most dominate landscape type of SBR was the natural forest landscape which occupied the area of $46.23 \%$ in 1980 and slightly decreasing to $44.38 \%$ and $44.40 \%$ in 2002 and 2010, respectively. Meanwhile, the moderate dominant landscape type was the agriculture. On the contrary, the least dominant landscape type was the miscellaneous landscape where covered the area of $1.29 \%$ in 1980 and had increased to $3.4 \%$ and $3.64 \%$ in 2002 and 2010 , respectively.

As shown in Table III, in the first period between 1980 and 2002, the disturbed forest and the natural forest landscapes were only two landscape types that decreasing in their area per annum at 4.11 and 1.37 sq.km, respectively. The forest plantation, on the other hand, was the most increasing in its area at $1.88 \mathrm{sq} . \mathrm{km}$ per annum. In the second period between 2002 and 2010, the disturbed forest landscape continually to decrease in its area, contrast to the agriculture, urban, and miscellaneous landscapes were constantly increasing in its areas.

TABLE III: EVALUATION OF LANDSCAPE CHANGES IN 1980, 2002, AND 2010

\begin{tabular}{lllllll}
\hline & \multicolumn{3}{c}{ Changes in 1980-2002 } & \multicolumn{2}{c}{ Changes in 2002-2010 } \\
\cline { 2 - 7 } $\begin{array}{l}\text { Landscape } \\
\text { Type }\end{array}$ & $\begin{array}{l}\text { Area } \\
\text { Change } \\
\left(\mathrm{Km}^{2}\right)\end{array}$ & $\begin{array}{l}\text { Change } \\
\text { per } \\
\text { annum }\end{array}$ & $\begin{array}{l}\text { Area } \\
\text { Change } \\
\left(\mathrm{Km}^{2}\right)\end{array}$ & $\begin{array}{l}\text { Change } \\
\text { per } \\
\text { annum }\end{array}$ \\
\hline $\mathrm{A}$ & 28.87 & 1.77 & 1.31 & 3.67 & 0.22 & 0.46 \\
$\mathrm{NF}$ & -30.10 & -1.85 & -1.37 & 0.25 & 0.02 & 0.03 \\
$\mathrm{DF}$ & -90.48 & -5.54 & -4.11 & -11.24 & -0.69 & -1.41 \\
FP & 41.39 & 2.53 & 1.88 & -7.03 & -0.43 & -0.88 \\
$\mathrm{U}$ & 15.98 & 0.98 & 0.73 & 10.44 & 0.64 & 1.31 \\
M & 34.34 & 2.11 & 1.56 & 3.91 & 0.24 & 0.49 \\
\hline Note: A A & A & &
\end{tabular}

Note: $\mathrm{A}=$ Agriculture, $\mathrm{NF}=$ Natural Forest, $\mathrm{DF}=$ Disturbed Forest, FP = Forest Plantation, $\mathrm{U}=\mathrm{Urban}, \mathrm{M}=$ Miscellaneous landscape 


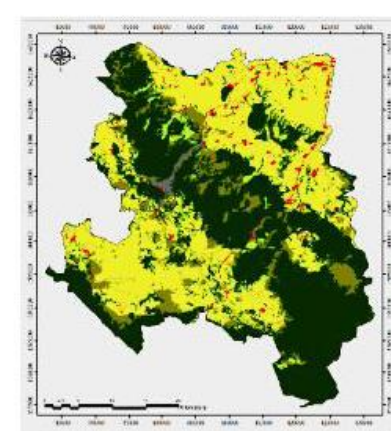

(a)

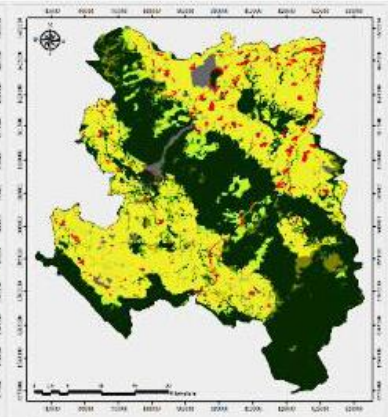

(b)

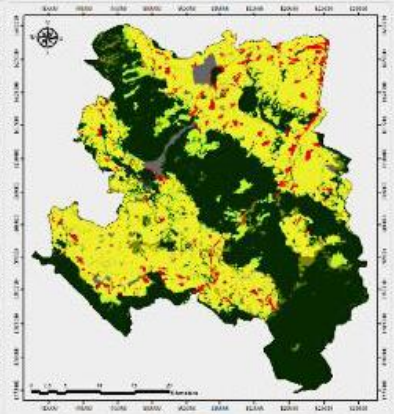

(c)

Fig. 3. Landscape type distribution in (a) 1980, (b) 2002, and (c) 2010.

\section{B. Landscape Metrics Measurement and Evaluation at Landscape and Class Levels}

Two levels of ecological landscape measurements including landscape and class levels were conducted using landscape indices for SBR landscape pattern measurement and evaluation. The selected landscape indices were included:

1) Area/edge metrics: Number of Patch (NP) and Edge Density (ED)

2) Shape metrics: Mean Shape Index (MSI)

3) Core Area metrics: Mean Core Area (MCA), and

4) Diversity/Interspersion/Isolation metrics: Shannon's Diversity Index(SDI),Interspersion Juxtaposition Index (IJI), and Mean Nearest Neighbor (MNN).

The definition and equation of all those indices were described in detail by McGarigal and Mark [29]; McGarigal et al. [30]; and Rempel and Carr [31]. The calculation of landscape indices and analysis of landscape pattern used their developed software FRAGSTAT and Patch Analyst packages. The short summary of indices description for interpretation indicated in Table IV.

\begin{tabular}{l|l}
\multicolumn{2}{l}{ TABLE IV: LANDSCAPE METRICS VALUE RANGES AND DESCRIPTIONS } \\
\hline Indices & Value Ranges and Descriptions \\
\hline NP & $\begin{array}{l}\text { NP } \geq 1, \text { without limit. NP }=1 \text { when the landscape contains } \\
\text { only } 1 \text { patch of the corresponding patch type. }\end{array}$ \\
\hline ED & $\begin{array}{l}\text { ED } \geq 0 \text {, without limit. ED }=0 \text { when there is no class edge } \\
\text { in the landscape }\end{array}$ \\
\hline MSI & $\begin{array}{l}\text { MSI } \geq 1, \text { without limit. MSI measures patch shape } \\
\text { complexity. MSI is } 1 \text { when all patches are circular and } \\
\text { increases as the patches become more irregular or complex. }\end{array}$ \\
\hline MCA & $\begin{array}{l}\text { MCA } \geq 0, \text { without limit. MCA is the average interior area } \\
\text { of patches in the different class or landscape. }\end{array}$ \\
\hline IJI & $\begin{array}{l}\text { IJI } \geq 1 \leq 100, \text { IJI measures patch adjacency. IJI approaches } \\
100 \text { when all patch types are equally adjacent to each other. }\end{array}$ \\
\hline MNN & $\begin{array}{l}\text { MNN } \geq 1, \text { without limit. MNN is the average of the } \\
\text { shortest distances between patches of the same type within } \\
\text { the landscape. }\end{array}$ \\
\hline SDI & $\begin{array}{l}\text { Index reflects the relative distribution in area between } \\
\text { patch types. Spatial distribution is not accounted for. }\end{array}$ \\
\hline
\end{tabular}

Landscape level: Landscape patterns were analyzed to fulfill four aspects of landscape ecology measurement using seven indices. Qualitative and quantitative evaluation of landscape indices in 1980, 2002, and 2010 were summarized as shown in TableV and described separately in each aspect.

1) Area/edge metrics. It was found that NP showed trend of increasing from 1980, 2002 to 2010 at 2,064, 2239, and 2293 patches, respectively. Meanwhile, ED had increased from 1980 to 2002, and slightly decreased in 2010. The indices implied that SBR landscapes had high tendency of fragmentation from 1980 to 2002, but became slightly fragmented from 2002 to 2010 .

TABLE V: LANDSCAPE METRICS MEASUREMENT AT LANDSCAPE LEVEL IN 1980, 2002, AND 2010

\begin{tabular}{llllcc}
\hline \multirow{2}{*}{$\begin{array}{l}\text { Landscape } \\
\text { Indices }\end{array}$} & \multicolumn{3}{c}{ Year } & \multicolumn{3}{c}{ Change } \\
\cline { 2 - 6 } & 1980 & 2002 & 2010 & $1980-2002$ & $2002-2010$ \\
\hline NP & 2064 & 2239 & 2293 & 175 & 54 \\
ED (m/ha) & 35.78 & 39.59 & 38.28 & 3.81 & -1.31 \\
MSI & 2.14 & 2.23 & 2.21 & 0.09 & -0.02 \\
MCA (ha) & 29.33 & 24.27 & 24.66 & -5.06 & 0.39 \\
SDI & 1.14 & 1.20 & 1.20 & 0.06 & 0.00 \\
IJI & 68.45 & 72.69 & 73.49 & 4.24 & 0.80 \\
MNN (m) & 190.4 & 207.8 & 200.8 & 17.40 & -7.00 \\
\hline
\end{tabular}

2) Shape metrics. The MSI showed gradually changed from $2.14,2.23$, to 2.21 in 1980,2002 , and 2010 , respectively. This notified that shape complexity of the landscape had slightly changed to less complexity and became simpler shapes.

3) Core area metrics. It was found MCA decreased from 1980 to 2002, and slightly increased from 2002 to 2010 . The indices revealed that the study area loss its interior habitat during 1980 to 2002 but gained some areas between 2002 and 2010.

4) Diversity/Interspersion/Isolation metrics. SDI increased from 1.14 to 1.21 in 1980 to 2002 and remained rather constant at 1.2 in 2010 . It implied that the landscape became more divert with different landscapes types in the area. IJI indicated the aggregation of the patches in the landscape; it had increased from 1980 to 2010. MNN showed the degree of isolation of patches in the landscape that was increased from 1980 to 2010.

Class level: Six indices were calculated and the results were reported in Table VI. Comparisons of landscape indices evaluation in 1980, 2002, and 2010 were described as the following.

1) Area/edge metrics. It was found that NP in theurban landscape significantly revealed high changed from 434 , 739, and 795 patches, similarly, the miscellaneous landscapesshowed increasing of NP from 271, 362, and 398 patches in 1980, 2002, and 2010, respectively. Contrast tothe natural forest, disturbed forest, forest plantation, and the agricultural landscapesin which decreasing in NP from 1980 to 2010.

Decreasing in ED in the natural forest and the disturbed landscapesand increasing inEDin the agriculture, forest 
plantation, urban, and the miscellaneous landscapes from the 1980 to 2010 revealed less fragmentations in the natural forest landscape and re-habitability might occur in some parts of the disturbed forest landscape. By contrast, other landscape types appeared to be more fragmented.

2) Shape metrics. In the agriculture, nature forest, disturbed forest, forest plantation, and the miscellaneous landscapes, their MSI value showed gradually increasing from 1980 to 2010. Meanwhile, the urban landscape showed decreasing of change. It was clearly that the urban landscape showed less complexity in its shape than other landscape types.

3) Core area metrics. MCA in the agriculture, forest plantation, urban, and the miscellaneous landscapes had the same trend of increasing in their interior habitat from 1980 to 2010. This indicated those of landscape type had gained amount of their core habitat. Contrast to the disturbed forest landscape showed decreasing their interior area from 1980 to 2010 which revealed that the disturbed forest landscape had changed to different landscape type.

4) Interspersion/isolation metrics. In the agriculture and the natural forest landscape had tendency of increasing in IJI values from 1980 to 2010. This indicated that aggregation of the patches in the natural forest and the agriculture landscapes were increased. On the other hand, IJI in the disturbed forest, forest plantation, and the miscellaneous landscapes showed low degree of changes from 1980 to 2010. The forest plantation landscape showed the highest MNN from 1980 to 2010. This implied that the forest plantation patches were sparsely distributed from each other in the landscape. Meanwhile, the agriculture landscape showed slightly change and had low MNN values meant that the agriculture landscape patches had maintained their aggregation.

TABLE VI: LANDSCAPE Metrics MEasurement at Class LeVEL IN 1980, 2002, AND 2010

\begin{tabular}{|c|c|c|c|c|c|c|}
\hline \multirow{2}{*}{ Indices } & \multicolumn{6}{|c|}{ Landscape Indices Values at Class level in $1980 / 2002 / 2010$} \\
\hline & A & NF & DF & FP & $\mathrm{U}$ & M \\
\hline \multirow{3}{*}{ NP } & $413^{\mathrm{a}}$ & 384 & 447 & 115 & 434 & 271 \\
\hline & $292^{b}$ & 357 & 395 & 94 & 739 & 362 \\
\hline & $279^{c}$ & 353 & 377 & 91 & 795 & 398 \\
\hline \multirow{3}{*}{$\begin{array}{l}\text { ED } \\
(\mathrm{m} / \mathrm{ha})\end{array}$} & 24.21 & 23.29 & 11.12 & 1.99 & 5.33 & 3.52 \\
\hline & 28.05 & 22.5 & 8.26 & 3.64 & 9.23 & 5.4 \\
\hline & 27.61 & 19.84 & 7.41 & 3.14 & 10.21 & 6.26 \\
\hline \multirow{3}{*}{ MSI } & 1.92 & 2.44 & 1.99 & 1.74 & 2.53 & 1.84 \\
\hline & 2.16 & 2.67 & 2.11 & 2.00 & 2.29 & 1.90 \\
\hline & 2.13 & 2.61 & 2.10 & 1.89 & 2.33 & 1.89 \\
\hline \multirow{3}{*}{$\begin{array}{l}\text { MCA } \\
\text { (ha) }\end{array}$} & 65.74 & 38.05 & 20.83 & 18.96 & 1.27 & 3.26 \\
\hline & 69.76 & 33.45 & 8.25 & 47.14 & 2.42 & 4.38 \\
\hline & 75.69 & 39.31 & 7.44 & 47.94 & 2.18 & 5.36 \\
\hline \multirow{3}{*}{ IJI } & 74.98 & 63.1 & 61.55 & 60.74 & 53.41 & 56.73 \\
\hline & 81.12 & 69.98 & 63.03 & 60.2 & 43.9 & 53.84 \\
\hline & 83.26 & 71.49 & 63.60 & 62.13 & 42.90 & 52.97 \\
\hline \multirow{3}{*}{$\begin{array}{l}\text { MNN } \\
\text { (m) }\end{array}$} & 52.73 & 135.74 & 207.63 & 582.57 & 171.79 & 312.44 \\
\hline & 43.67 & 148.2 & 297.67 & 555.65 & 182.87 & 261.43 \\
\hline & 44.11 & 136.3 & 323.93 & 560.59 & 167.82 & 234.64 \\
\hline
\end{tabular}

\section{CONCLUSION}

The study indicated that landscape change analysis using satellite data to track changes made to the area over time provided useful and effective information. Additionally, the analysis of the spatial pattern distribution using landscape metrics also helped explain the details of the landscape structure even more, not only the extent of the area but the various features had also been measuring, such as the shape complexity, pattern distribution, fragmentation and isolation of the patches in the landscape. Thus, it is demonstrated that the application of satellite data and landscape metrics can be used effectively to measure and evaluate the changes and structure conditions of each landscape type and also provided useful information for further research in the future.

\section{ACKNOWLEDGMENT}

The authors would like to express thankfulness and appreciation to Space Technology Development Agency (GISTDA) and Suranaree University of Technology, whose provided satellite data and other materials for this study.

\section{REFERENCES}

[1] J. M. Read and N. S. Lam, "Spatial methods for characterizing land cover and detecting land cover changes for the tropics," International Journal of Remote Sensing, no. 23, pp. 2457-2474, 2002.

[2] M. A. Wulder, R. J. Hall, N. Coops, and S. E. Franklin, "High spatial detail remotely sensed data for ecosystem characterization," BioScience, vol. 54, pp. 511-521, 2004.

[3] P. A. Townsend, T. R. Lookingbill, C. C. Kingdon, and R. H. Gardner, "Spatial pattern analysis for monitoring protected areas," Remote Sensing of Environment, vol. 113, pp. 1410-1420, 2009.

[4] P. Coppin, I. Jonckheere, K. Nackaerts, and B. Muys, "Digital change detection methods in ecosystem monitoring: A review," International Journal of Remote Sensing, vol. 10, pp. 1565-1596, 2004.

[5] D. Rocchini, G. L. W. Perry, M. Salerno, S. Maccherini, and A Chiarucci, "Landscape change and the dynamics of open formations in a natural reserve," Landscape and Urban Planning, vol. 77, pp. 167-177, 2006.

[6] P. Coppin, I. Jonckheere, K. Nackerts, and B. Muys, "Digital change detection methods in ecosystem monitoring: A review," International Journal of Remote Sensing, vol. 25, pp. 1565-1596, 2004.

[7] J. M. Read and N. S. Lam, "Spatial methods for characterizing land cover and detecting land cover changes for the tropics," International Journal of Remote Sensing, vol. 23, pp. 2457-2474. 2002.

[8] G. M. Turner, "Disturbance and landscape dynamics in a changing world," Ecology, vol.10, pp. 2833-2849, 2010.

[9] R. H. Fraser, I. Olthof, and D. Pouliot, "Monitoring land cover change and ecological integrity in Canada's national parks," Remote Sensing of Environment, vol. 113, pp. 1397-1409, 2009.

[10] R. Haines-Young, "Land use and biodiversity relationships," Land Use Policy, vol. 26, pp. 5178-5186, 2009

[11] A. B. Leitao and J. Ahern, "Applying landscape ecological concepts and metrics in sustainable landscape planning," Landscape Urban Planning, vol. 59, pp. 65-93, 2002.

[12] G. M. Turner, R. H. Gardner, and R.V. O'Neill, Landscape Ecology in Theory and Practice Pattern and Process, Springer-Verlag, New York, 2001, p. 352.

[13] J. L. Pfund, P. Koponen, T. O’Connor, J. M. Boffa, M. Noordwijk, and J. P. Sorg, "Biodiversity conservation and sustainable livelihoods in tropical forest landscapes," Patterns and Processes in Forest Landscape, pp. 297-322, 2008.

[14] M. Antrop, "Reflecting upon 25 years of landscape ecology," Landscape Ecology, vol. 22, pp. 1441-1443, 2007.

[15] M. A. Wulder and S. E. Franklin, Understanding Forest Disturbance and Spatial Pattern: Remote Sensing and GIS approaches, New York: Taylor \& Francis, 2007, p. 246

[16] D. Duro, N. C. Coops, M. A. Wulder, and T. Han, "Development of a large area biodiversity monitoring system driven by remote sensing," Progress in Physical Geography, vol. 31, pp. 235-260, 2007.

[17] M. A. Wulder, R. J. Hall, N. Coops, and S. E. Franklin, "High spatial detail remotely sensed data for ecosystem characterization," BioScience, vol. 54, pp. 511-521, 2004.

[18] S. E. Franklin, "Remote sensing for sustainable forest management," Lewis and CRC Press, Boca Raton, Florida, 2001, p. 470.

[19] A. M. Lechner, J. K. Reinke, Y. Wang, and L. Bastin. Interactions between landcover pattern and geospatial processing methods: Effects on landscape metrics and classification accuracy. Ecological Complexity. [Online]. Available: http://dx.doi.org/10.1016/j.ecocom.2013.03.003 
[20] S. Su, R. Xiao, Z. Jiang, and Y. Zhang, "Characterizing landscape pattern and ecosystem service value changes for urbanization impacts at an eco-regional scale," Applied Geography, vol. 34, pp. 295-305, 2012.

[21] R. C. Corry and J. I. Nassauer, "Limitations of using landscape pattern indices to evaluate the ecological consequences of alternative plans and designs," Landscape Urban Planning, vol. 72, pp. 265-280, 2005.

[22] J. P. G. Jones, "Monitoring species abundance and distribution at the landscapescale," Journal of Apply Ecology, vol. 48, pp. 9-13, 2011.

[23] S. Sutthivanich, "Effects of fire frequency on vegetation in dry dipterocarp forest at Sakaerat, ChangwatNakhonratchasima," MSc. thesis, Faculty of Forestry, Kasetsart University, Bangkok, 1989.

[24] Y. Trisurat, "Land use and forested landscape changes at Sakaerat Environmental Research Station in NakhonRatchasima Province," Thailand, Ekológia (Bratislava), vol. 29, pp. 99-109, 2010.

[25] Y. Trisurat and P. Duengkae, "Consequences of land use change on bird distribution at Sakaerat Environmental Research Station," Journal of Ecology and Field Biology, vol. 34, pp. 203-214, 2011.

[26] P. Sahunalu, P. Dhanmanonda, M. Jamroenpruksu, and C. Khemnark, "Effects of restoration, abandoned areas and natural forests on Sakaerat environment," Final report submitted to the National research council, Faculty of Forestry, Kasetsart University, Bangkok, Thailand, 1993.

[27] Thailand Institute of Scientific and Technological Research, General information. [Online]. Available: http://www.tistr.or.th/sakaerat/index.php

[28] I. Sutthivanich, "Integration of landscape ecology metrics with remotely sensed data for forest restoration and management in Sakaerat Biosphere reserve, NakhonRatchasima, Thailand," Ph.D. dissertation, Institute of Science, Suranaree University of Technology, Nakhon Ratchasima, Thailand, 2012.

[29] K. McGarigal and B. J. Marks, "FRAGSTATS, Spatial pattern analysis program for quantifying landscape structure," Reference Manual. Forest Science Department Oregon State University, Corvallis, Oregon, 1995.

[30] K. McGarigal, S. A. Cushman, M. C. Neel, and E. Ene, "Fragstats: spatial pattern analysis program for categorical maps," Computer software Program, University of Massachusetts, Amherst, USA, 2002.
[31] R. S. Rempel, D. Kaukinen, and A. P. Carr, "Patch analyst and patch grid," Ontario Ministry of Natural Resources, Centre for Northern Forest Ecosystem Research, Thunder Bay, Ontario, 2012.

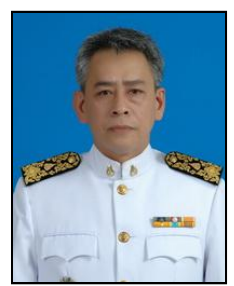

Suwit Ongsomwang is with the School of Remote Sensing, Institute of Science, Suranaree University of Technology, Thailand. He got the Ph.D. degree in the field of remote sensing and geographic information system from Technical University of Berlin, Germany. $\mathrm{He}$ is a lecturer in the School of Remote Sensing for almost 10 years. He advises to the large numbers of master and doctoral students. $\mathrm{He}$ has great experiences, broad vision and previously worked in executive level with the government sector over 20 years. He specializes in forestry, including forest management, natural resources and environmental conservation. His research interests are geoinformatics science, remote sensing, geographic information system, and global positioning system applications on forestry, ecology, land use and land cover, natural and environmental resources management. He published more than 40 technical and research papers both in Thai and English. He consulted to several project works.

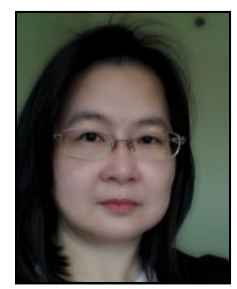

Intareeya Sutthivanich is with the School of Remote Sensing, Institute of Science, Suranaree University of Technology, Thailand. She got the Ph.D. degree in the field of geoinformatics from Suranaree University of Technology. Her Ph.D. dissertation is "Integration of landscape ecology metrics with remotely sensed data for forest restoration and management in Sakaerat Biosphere Reserve" and her research interests are geoinformatics science, including remote sensing and geographic information system applications on forest ecology, landscape ecology, natural resources, and environmental conservation. She attended to many local, regional and international meeting, workshops, training programs, and papers presentation to national and international conferences related to those research areas. 